\title{
Evaluation of Strategic Factors in the Implementation of the Online Tax System in DKI Jakarta Province:
}

\author{
Efforts to Answer Challenges in the New Normal Era
}

\author{
Oktaviany Puspitalia*, Inayati, Lucas Filberto Sardjono \\ Department of Fiscal Administration, Faculty of Administrative Science \\ Universitas Indonesia \\ Depok, Indonesia \\ *oktaviany.puspitalia@ui.ac.id, Inayati.hifni01@gmail.com, Lucas.filberto@gmail.com
}

\begin{abstract}
In the current New Normal era, service activities are conducted online to reduce the risk of a wider spread of the COVID-19 virus. The DKI Jakarta Provincial Government has provided online-based services for regional taxpayers through a website and a mobile application. However, there are still several challenges in implementing these services. This study analyzes the strategic factors that influence the DKI Jakarta online tax system's implementation using the Human Organization Technology (HOT) Fit Model approach (2008). This research uses a quantitative approach by distributing questionnaires to 100 respondents who have used the DKI Jakarta Online Tax System in 2020. The result indicates that four strategic factors, namely influence the implementation of online tax policies in DKI Jakarta: 1) Support and response from the online system to taxpayers in using the online system (Service Quality); 2) Taxpayer's perception of the benefits and convenience in using the online tax system (User Satisfaction); 3) Service provider organization (Environment); 4) Support from the system in fulfilling taxpayers' rights and obligations (Net Benefit). Based on these findings, the DKI Jakarta Provincial Government can formulate a strategy to improve online-based services to address the New Normal era's challenges.
\end{abstract}

Keywords-strategic factors, HOTFit models, online Tax System, DKI Jakarta Province

\section{INTRODUCTION}

The implementation of New Normal during the COVID-19 pandemic has proven to be quite challenging for the government, particularly in providing excellent public services in numerous fields. In the midst of taxing circumstances and precariousness of the New Normal era, the government needs to create good public policy conditions. With good public policy conditions, i.e., sustainable public policy conditions, it can be assumed that society can enjoy the achievement of a sustainable net benefit in the form of an optimal solution for a specific public issue in the long-term [1]. The Indonesian government is currently trying to establish good and uninterrupted public services during the COVID-19 pandemic by using the New Normal era approach. Public organizations bear the responsibility to provide public services to meet society's needs, which are given regarding good governance principles, namely oriented towards the impact received by society [2].

One of the alternatives in providing sustainable benefits to the community amid the New Normal era while also minimizing risks of spreading the disease, the government has shifted to online public services. According to The World Bank [3] "E-Government refers to the use by government agencies of information technologies such as Wide Area Networks (WANs), the Internet, and mobile computing that can transform relations with citizens, businesses, and other arms of government...".

DKI Jakarta Province has adopted e-government in regional taxation as a form of innovation in public services. There are a range of benefits to delivering public services through an online system than the conventional one, namely increasing the services' efficiency, transparency, and trustworthiness. Innovation in public services provisions is the government's initiative to address the ongoing problems of society's growing demand for public services despite the limited resources owned by the government or public organizations [4]. The DKI Jakarta Provincial Government (Bappeda) has launched an innovative regional tax service through a website at www.pajakonline.jakarta.go.id and a mobile application that can be accessed via a smartphone. This service aims to increase public tax compliance with technology by providing easier access to regional tax payment services, reporting, and verification.

It is irrefutable that there are risks of failure which could happen during the implementation of an online system. Factors that may cause system failure include the system's incompatibility with business processes and the organization's information. The system failure can also be triggered by technical and non-technical factors related to the user perceptions of the online tax application system, which also influences users' willingness to use the service. 
As of May 18, 2020, Play Store recorded more than 100.000 downloads of the DKI Jakarta Province Online Tax Service mobile application. This application is rated 2.7 out of 5 from 556 users. This rate indicates negative feedback from the users. Most negative feedback was caused by the errors in the online system. Meanwhile, the least frequent negative feedback was due to users' inability to understand and operate the Online Tax application. Most positive feedback comes from the Online Tax application's adequacy, while the time efficiency caused the least frequent positive feedback due to the use of the application.

To increase the utility of the online tax application system, it is necessary to study the strategic factors that influence the online tax system's implementation. The strategic factors will be studied using the Human Organization Technology (HOT) Fit Model. Human Organization Technology (HOT) Fit Model provides a framework to evaluate an information system by using three principal components or determinants in an information system, namely Human, Organization, and Technology, as well as a sustainable relationship between the three [5].

HOTFit model consists of two evaluation system models, namely the IS Success Model [6] and IT Organization-Fit Model [7]. These models are considered to identify main elements in an organization that may influence IS and emphasize the harmony between the two. The HOTFit model framework consists of information quality, system quality friendly, service quality, system use, user satisfaction, environment, net benefit, and organization structure (Figure 1).

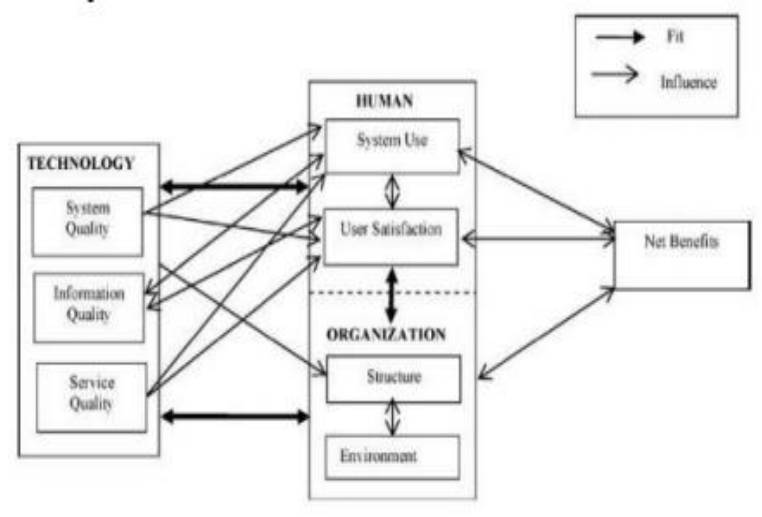

Fig. 1. HOTFit Model Source: Yusof et al. [5].

Variables and indicators from HOTFit Model adopted for the research are a combination of the IS Success Model by Delone and McLean and the IT Organization-Fit Model [6]. The hypotheses of this research are as follows:

Ho: Strategic Factors (Information Quality, System Quality, Service Quality, System Use, User Satisfaction, Environment, Net Benefit, Structure Organization) has a significant effect on implementing the Online Tax System in DKI Jakarta Province.
Ha: Strategic Factors (Information Quality, System Quality, Service Quality, System Use, User Satisfaction, Environment, Net Benefit, Structure Organization) do not affect the implementation of the Online Tax System in DKI Jakarta Province.

\section{RESEARCH METHOD}

This research was conducted using a quantitative approach with mixed-method data collection. The non-probability sampling technique was used on regional taxpayer respondents of DKI Jakarta Province who have been actively using the online tax application. In addition, the researchers conducted an unstructured interview with the Head of Bappeda in DKI Jakarta Province.

This study's population was individual taxpayers of DKI Jakarta Province who have utilized the online tax application and possessed taxable objects under their respective names. The total number of respondents who took part in this study was 100 people. Descriptive statistics analysis was conducted using the mean to calculate each class's limit with a measurement scale.

This research used the Likert scale with a range of $1-5$. The statistical test was carried out with the Adjusted R2 Test (Coefficient of Determination) to measure the ability of the HOTFit model in explaining the variability of independent variables. F Test (Multiple Linear Significance) shows the significant effect of all independent variables included in the model jointly on the dependent variable. Significance can be directly seen from the probability value. If P-value is less than $\alpha$ (for example, $\alpha=5 \%$ or 0.05 ), then the independent variable influences the dependent variable, or in other words, Ho is rejected. The T-Test (Partial Significance) is used to examine the significance of each independent variables individually in explaining dependent variables as follows:

- $\mathrm{H} 0: \beta=0$, meaning the coefficient value equals to zero;

- $\mathrm{H} 1: \beta 1 \neq 0$, meaning the coefficient value is not equal (different) to zero.

\section{RESULTS AND DISCUSSION}

The multicollinearity test examines the Tolerance dan Variance Inflation Factor (VIF) on a regression model or compares the values of the individual coefficient of determination $\left(\mathrm{r}^{2)}\right.$ with a standard value of determination $\left(\mathrm{R}^{2}\right)$. The limit value of VIF is less than 10 , and the tolerance value is greater than 0.1 . The basis of decision-making in a multicollinearity test is a tolerance value greater than 0.1 and a VIF value less than 10. The Coefficients shows that VIF and Tolerance from eight variables have tolerance values greater than 0.1 and VIF less than 10. Therefore, it can be concluded that there is no multicollinearity between the eight dimensions.

The result from the normality test of this study indicates that the distribution of data is normal. The One-Sample Kolmogorov-Smirnov Significance Value Test's normality test 
shows a value of $0.618(0.618>0.05)$. According to this test, it can be concluded that the residual value of the data is normally distributed. Lilliefors Test for Normality was also carried out and indicated a Significance Value of 0.174 (0.174>0.05); hence, the data's residual value is normally distributed.

The heteroscedasticity test with criteria of significance value > 0.05 resulted in the following significance values: information quality of 0.415 , system quality of 0.797 , service quality of 0.771 , system use of 0.316 . User satisfaction of 0.181 , the environment of 0.252 , the net benefit of 0.055 , and structural organization of 0.565 . Based on the Significance Value of independent variables, which are greater than 0.05 , it can be concluded that heteroscedasticity does not occur.

\section{A. Coefficient of Determination}

The adjusted R2 test is used to measure the model's ability to explain the independent variables' variations. The coefficient of determination value is between zero and one. A low R2 value means that independent variables have constrained capability in explaining the variation of the dependent variable. Values close to one indicate that independent variables manage to provide almost all the information required to predict dependent variables [8].

The coefficient of determination from the Adjusted $\mathbf{R}$ Square regression analysis output shows a value of 0.909 $(90,9 \%)$. The coefficient of determination aims to determine the percentage of influence of variable $(\mathrm{X})$ simultaneously $(\mathrm{Y})$. Results show that $90,9 \%$ of the eight variables' variations can be explained in the implementation of the online tax system.

The simultaneity test (F Test) aims to see the correlation between tested variables. The basis of decision-making is Significance $<0.05$ (Significant Effect). Results of the F test show that Sig. F. Change Value Hasil is lower than the margin of error, which also indicates that the Regression Model is compatible with the independent variables. The model used can explain the effect of an independent variable, The Implementation of Online Tax System in DKI Jakarta Province, on the dependent variable, namely HOTFit Models. Therefore, it can be assumed that $\mathrm{H}_{0}$ and $\mathrm{H}_{1}$ are accepted with a Sig. F. Change value of 0.000 , less than the margin of error value or the limit of acceptable error in social sciences research, which is 0.05 . Based on the results of F test, it can be concluded that Information Quality, System Quality, Service Quality, System Use, User Satisfaction, Environment, Net Benefit, and Structure Organization dimensions have a significant effect simultaneously on the Implementation of Online Tax System.

Partiality test (t-Test) was carried out and showed a significance value greater than 0.05 with the following details: Information Quality is 0.104, System Quality is 0.903, Service Quality is 0.017, Significance Value of System Use is 0.233 . User Satisfaction is 0.025 , the environment is 0.000 , Net Benefit is 0.000, and Structure Organization is 0.403 .
Data analysis results indicate that Information Quality, System Quality, System Use, and Structure Organization do not have partially significant effects on the Implementation of the Online Tax System in DKI Jakarta Province. Meanwhile, Service Quality, User Satisfaction, Environmental, and Net Benefit variables have partially positive significant effects on the Online Tax System's implementation.

Multiple regression analysis explains that Information Quality has a positive Regression Coefficient value of 0.022 , meaning that an increase in Information Quality will increase the use of the Online Tax System. System Quality also has a positive Regression Coefficient value of 0.002 , meaning that an increase in System Quality will also increase in utilizing the implementation of the Online Tax System in DKI Jakarta Province. Service Quality has a positive Regression Coefficient value of 0.045, which means that an increase in Service Quality affects the utilization of the online tax system's implementation. System Use also has a positive Regression Coefficient value of 0.024 , which means an increase in System Use will influence the utilization of the online tax system's implementation.

User Satisfaction has a positive Regression Coefficient value of 0.053 , meaning that an increase in User Satisfaction affects the increase in the Online Tax System's implementation in DKI Jakarta Province. The environment has a positive Regression Coefficient value of 0.060 , meaning that an increase in the environment will increase the Online Tax System's implementation in DKI Jakarta Province. Net Benefit has a positive Regression Coefficient value of 0.118 , indicating that an increase in Net Benefit will also influence the implementation of the Online Tax System in DKI Jakarta Province. Structure Organization variable has a positive Regression Coefficient value of 0.012 , which means that an increase in Structure Organization will also increase the Online Tax System's implementation.

The statistical test results show that several factors determine the success of online tax system implementation in DKI Jakarta. First, the users' need for service quality has a more significant effect on the implementation of the online tax system than the design of the application itself. For instance, users require a service to meet their needs and the follow-up on problems they encountered when using the online system. This factor indicates that while it is important to provide public services through an online system, the service provider's response in resolving users' problems is also essential to determine the success of online tax system implementation.

Second, users' perception of the benefits of the online system and convenience when using the system also shows a significant effect on the success of online tax system implementation. Implicitly, these findings suggest the need for system improvement in providing features and design to support tax obligations fulfillment and encourage optimal use of the online system.

Third, other than factors regarding the system and service, the environment also affects the success of online tax system 
implementation in DKI Jakarta. Bappeda's support as the primary stakeholder of the service immensely affects the success of implementation as well. For instance, Bappeda's ability to communicate with the public about the online tax system policy is crucial in influencing the implementation's success.

Fourth, the last factor that significantly promotes the success of online tax system implementation is the users' benefits from the application. The benefits that users consider essential are cost efficiency, time efficiency, ease in decisionmaking on the fulfillment of tax obligations, and reduction in risk of error when fulfilling tax obligations.

Generally, these four factors can be divided into two categories. The first category is the internal factor of the users. Fulfilling users' needs is a tremendously significant factor in promoting the success of online tax system implementation in DKI Jakarta. The second category is the users' external factor, namely the support from Bappeda as the primary stakeholder in providing online tax services.

\section{CONCLUSION}

This research indicates that Service Quality, User Satisfaction, Environment, and Net Benefit dimensions are the strategic factors affecting the success of the implementation of Online Tax Service in DKI Jakarta Province Online. Therefore, the DKI Jakarta Provincial Governments need to upgrade the online tax system by improving the four dimensions in the online tax application. Moreover, the research findings suggest that there is a positive correlation between independent and dependent variables. In other words, the higher the public's positive perception of the benefits obtained from the online tax system of DKI Jakarta, the more people will utilize the online tax application. Improvements need to be continuously done on the online tax system in DKI Jakarta Province to provide useful and sustainable services for the public.

\section{ACKNOWLEDGMENT}

This research's publication is funded by the PUTI Social Sciences Grant from the Directorate of Research and Community Engagement of Universitas Indonesia year 2020. Contract Number: NKB-2528/UN2.RST/HKP.05.00/2020.

\section{REFERENCES}

[1] D. Korenik and M. Węgrzyn, "Public Policy Timing in a Sustainable Approach to Shaping Public Policy," Sustainability, vol. 12, no. 7, p. 2677, 2020.

[2] A.T. Maria, M. Maquart, A. Makinson, O. Flusin, M. Segondy, I. Leparc-Goffart, V. Le Moing, and V. Foulongne, "Zika Virus Infections in Three Travellers Returning from South America and the Caribbean Respectively, to Montpellier, France, December 2015 to January 2016," Eurosurveillance, vol. 21, no. 6, p. 30131, 2016.

[3] R. Panzardi, C. Calcopietro, and E.F. Ivanovic, "New-Economy Sector Study Electronic Government and Governance: Lessons for Argentina," New-Economy Sect. Study Electron. Gov. Governance-Lessons from Argentina Retrieved, 2002.

[4] I. Vickers, F. Lyon, L. Sepulveda, and C. McMullin, "Public Service Innovation and Multiple Institutional Logics: The Case of Hybrid Social Enterprise Providers of Health and Wellbeing," Res. Policy, vol. 46, no. 10, pp. 1755-1768, 2017.

[5] M.M. Yusof, J. Kuljis, A. Papazafeiropoulou, and L.K. Stergioulas, "An Evaluation Framework for Health Information Systems: Human, Organization and Technology-Fit Factors (HOT-Fit)," Int. J. Med. Inform., vol. 77, no. 6, pp. 386-398, 2008.

[6] W.H. DeLone and E.R. McLean, "Measuring E-Commerce Success: Applying the DeLone \& McLean Information Systems Success Model," Int. J. Electron. Commer., vol. 9, no. 1, pp. 31-47, 2004.

[7] J.F. Morton, "The Horseradish Tree, Moringa Pterygosperma (Moringaceae) - a Boon to Arid Lands?," Econ. Bot., vol. 45, no. 3, pp. 318-333, 1991.

[8] I. Ghozali, Aplikasi analisis multivariate dengan program SPSS. Badan Penerbit Universitas Diponegoro, 2006. 